\title{
Experiments on the Virtual City: three-dimensional reconfigurations of missing, destroyed or never realized urban areas
}

\author{
Gian Marco GIRGENTI, Mauro FILIPPI, Federica MARRONE \\ Dipartimento di Architettura, SfeRA \\ University of Palermo \\ Palermo, Italy \\ gm.girgenti@unipa.it; fedemarrone@gmail.com; filimauro@gmail.com
}

\begin{abstract}
We present two works on the "Virtual City" held at Palermo. They are about the three-dimensional reconfiguration of urban places that show evidence of "invisible" architecture; this is because in one case there were ancient monuments now destroyed, or in another case projects designed for the urban void and never made. The aim is to involve new forms of communication for the development of cultural tourism.
\end{abstract}

Keywords: Virtual reconstruction - Urban analysis Augmented Reality Systems

\section{INTRODUCTION}

Architecture is substance, matter, weight, stone, but also design, plan, idea, strategy. The ambivalence of its nature, real and ethereal at the same time, makes the product range in vast and varied shapes. Today more than ever it is called to approach the world of technology and computer technology, experiencing issues in their complexity always related to the great changes which are taking place in society, and especially in its modus vivendi. During the evolution of technologies the computer has certainly played the role of a greater importance in being able to combine physical and virtual reality, its parallel twin. In 2011, even though it has lost its meaning as it has been supplanted by a new mixed reality: a technology that, "increasing" the physical reality of virtual entities and vice versa, in realtime, surpassed the old building simulations making a real immersive experience.

Technical progress in digital representation and assisted design develops over time to faster speeds and with a surprising pace. A little more than half a century after the manufacture of the first computer, forty years after the birth of the first graphical operating system and the Internet, after thirty years from the development of the first virtual scenes and just ten years after the design of mixed systems, today the range of possibilities available to operators is enormous and potentially unlimited. The architectural representation has suffered heavily for these innovations catapulting architects, designers and engineers in a new era that combines architecture/communication/fashion/marketing.

New social patterns require a renewed way of thinking about knowledge, of sharing it and of proposing it. Modern information is multimedial, multisensorial, interactive, and somewhat pervasive. We are moving towards a more personal and personalizing business proposal, which should be individual and collective at the same time. The watchwords of consumerism, "all " and "now", have a great number of applications. Probably, however, the price to pay in this rapidly changing communication channels will be the increasing superficiality of information coupled to a dispersive pervasiveness and ubiquity of the means of its transmission that will lead, finally, to a dangerous approval of many of its contents; even if, in the counterpart, as to this uninviting series of fact, we will also have a richer and more "democratic" supply of knowledge and a less and less sectorial access to information.

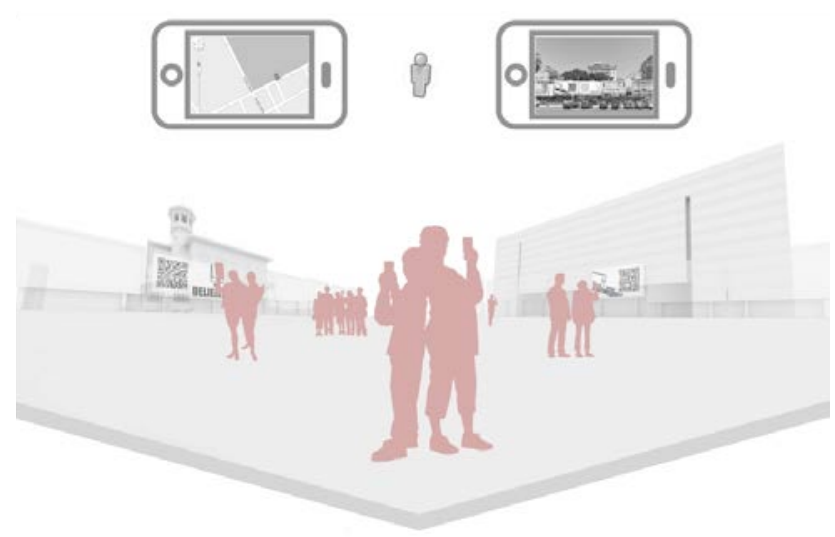

Figure 1. Simulation of the AR application by specific software for smartphone integrated with the QR-code system.

The objectives that proper education and proper training should pursue - looking to a future global circulation of ideas and to the formulation of a choral progress of knowledge- should be: keeping abreast of technology, maintaining a proper update on new findings and proposing new applications in unexplored areas.

Technological progress gallops at breakneck speed, leaving behind cultural processes with a degree of obsolescence more and more increasing and at the same time stimulating an unlimited thirst for innovation. This is the era of handheld devices and tablet-PC, of LEDs and of multi- 
touch systems, then we are in front of the undisputed triumph of information technology applied to all the fields of knowledge.

Architecture is not an exception. It has also suffered and continues to suffer the heavy influence of the digitalis and of the virtuality every day. There are still many debates on issues of computer aided design and integrated representation. But since the introduction of GIS and its initial integration with GPS, the general purpose was quite clear: synthesizing as much data as possible concerning a specific geo-referenced area and organizing information in layers available in a simple and direct way. The synthesis of information and the simplicity of its communication is the basic goal of most companies and institutions involved in research, whether general or sectorial.

The work proposed here will be part of that wide range of recent research on innovative applications and renewed use of information technologies in the fields of Architecture, and will offer an experience that embodies communication, design, history and analysis. Then a search that strays from pure compilation approaching as close as possible to the actual testing of the hypothesis. This research sought to study the application of "augmented reality" -one of the latest technologies to the market- to the representation of architecture, with the aim of developing a repeatable and continuously expandable information system that would allow a rapid and direct dissemination of information about certain architectural spaces in an innovative, simple and intuitive way [1].

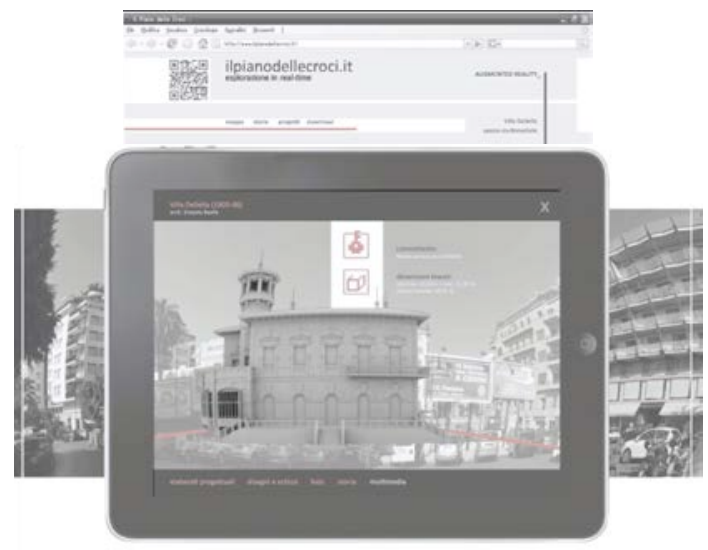

Figure 2. Simulation of a live exploration in Piazza F. Crispi and the realtive web page layout.

\section{FROM BASILE TO BOTTA: THE “INCREASED” HISTORY OF PALERMO "PIANO DELLE CROCI"}

For this specific work we have chosen the area of Piazza F. Crispi in Palermo, where up to fifty years ago there was the famous Villa Deliella by Ernesto Basile and where today unfortunately there is just an anonymous car park with the ghost of a project, that was never built, by architect Mario Botta[2].

So a story that tells of principals, ages, chronicles, architects, ideas, etc., a story of many aspirations and no surviving brick.

The example of Piazza Crispi (formerly known as "Plan of the Crosses") in Palermo, then was born as a repeatable model, an alternative way of understanding the history and the stories of different places of the city following thematic itineraries that add interactive nature of multimedia information "increasing" the range of traditionally given offerings. Piazza Crispi, therefore, as a start, as the first case of study, the first experimental approach, an area full of history and stories that have so much to tell and to show, and where the gaps are filled with invisible past and assumed architecture, in which time seems to have frozen in an exact moment when the ghosts of assumptions and unborn estimates are shaken. A scenery, therefore, full of ideas, the training of which is related to various times and aspects of the history of Sicilian architecture, representing one of the most emblematic urban junctions of the growing of Palermo in the last two centuries or more[3].

The final outcome is a semi-immersive experience, which combines virtuality and reality, which, through the use of a specific hardware aims to show to the observer the history of this place through a use in real-time. Ultimately an updated, convenient, portable, interactive and multimedial database for tourists and scholars interested in the city, even another possible city, actually trampling the asphalt of its streets[4].

In the attempt to propose a useful application research of the latest technologies in the areas which are traditionally investigated by architects, we tried to test a prototype in Palermo "Hyper-City" in a narrow field of inquiry. The choice of F. Crispi square, as experimentation area, was not random. For the historical significance that characterizes its urban stratification, for the artistic significance of architectural objects that have limited it and that nowaday minimally continue to do, and not the last, for the importance of its socio-political events that have assumed from the $60 \mathrm{~s}$ onwards, this space is more suitable than others to be told and represented[5]. The idea was to develop an integrated cultural and touristic hypothesis by the application of advanced technologies to propose a more complex and significant use of the site. Today Palermo presents a good supply of art throughout the territory, but it lacks of an adequate organizational support which may unite and coordinate the various urban areas in actual routes of art. Such a proposal might be, then, as a starting point for a more interesting and complex cultural operation, to read the present city in a path enriched (or "increased") with the many vicissitudes, large or small, of its long history.

The experience given here wants to pick up and tell, in this sense, the complexity of an exemplary place in the city of Palermo, empowering it through the implementation, on a single support, of text, sound, graphics, photography, videography and virtuality. The large amount of data obtained during the data collection process has unfortunately forced to work out only the scaffold of 


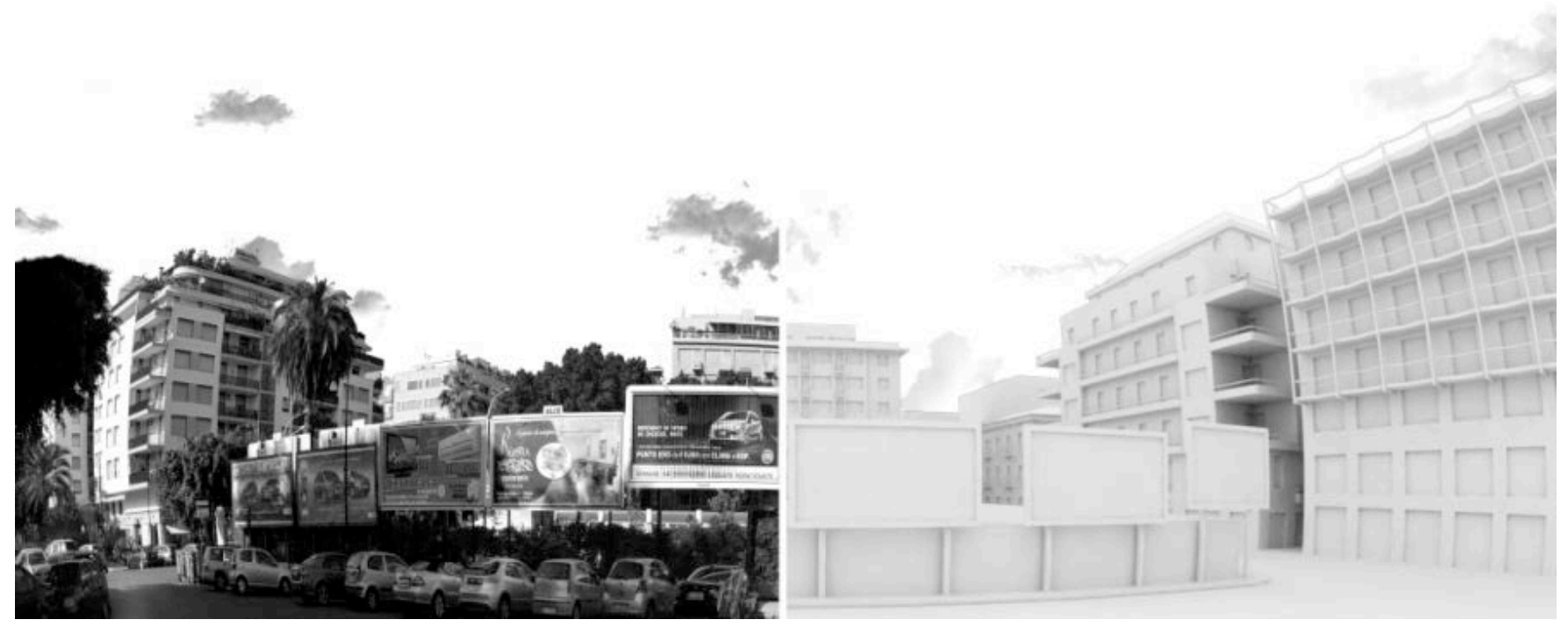

Figure 3. Overlay of the panorama of Piazza Francesco Crispi and his three-dimensional reconstruction.

assumed system, deepening on the other hand some of its aspects through the analysis of the two most significant project experiences in the story of its evolution: the Villa Deliella by Ernesto Basile (1904/05) and the Media Building by Mario Botta (1988). Two examples of "invisible" architecture to summarize the past, the present, and a "possible" future of the square[6].

The construction of three-dimensional digital model of the two projects and of the environment of the square, in its present and past shape, has been drawn as the first step in the construction of a hypothetical "digital atlas information" of Palermo. It will be enough to apply on each model its exact geographical coordinates (using GPS) in order to obtain that these will be perfectly coincident with their original physical models, allowing us to create a true system of Augmented Reality. The 3D digital model will thus become the 'scaffold' which will be attached to all information relating to the history and chronological evolution of the project. When the 3D model -related to the database containing all the multimedial information such as text, photos, movies, drawings, plans details, etc- will be made available on-line, the user will be allowed to visit the building questioning it with special ramifications of hypertext caught on specific "hot spots", and so constructing a personal approach to investigation. Combining the web and multimedia technology, then it will become possible to integrate the application of Augmented Reality to mobile UMTS, Android devices, and tablet-computer. The system becomes a real communication interface between the operator and archive, greatly simplifying the hypertext consultation of collected material. A particularly "democratic" and current solution, suitable to any level of professional or just learning research about the city. The information system proposed here is designed to overlap with urban spaces, to enclose and "amplify " them.
It might seem that the making of this product apparently doesn't belong to the traditional duties of an architect; on the contrary it is natural that, in the perspective of a renewed appreciation of the skill and in the light of new requirements to which this figure is properly responsible, he himself should be the main actor of this great turning point for skill upgrading. In this regard, the words of Paul Virilio are convincing: "Today we are in a phase change in reality, which is accelerated and at the same time increased by means of technology. We must build that kind of reality, and architects are in excellent conditions to do so. But before building the houses it will be necessary to rebuild reality along with other specialists, because it is not obviously only the job of architects" [7].

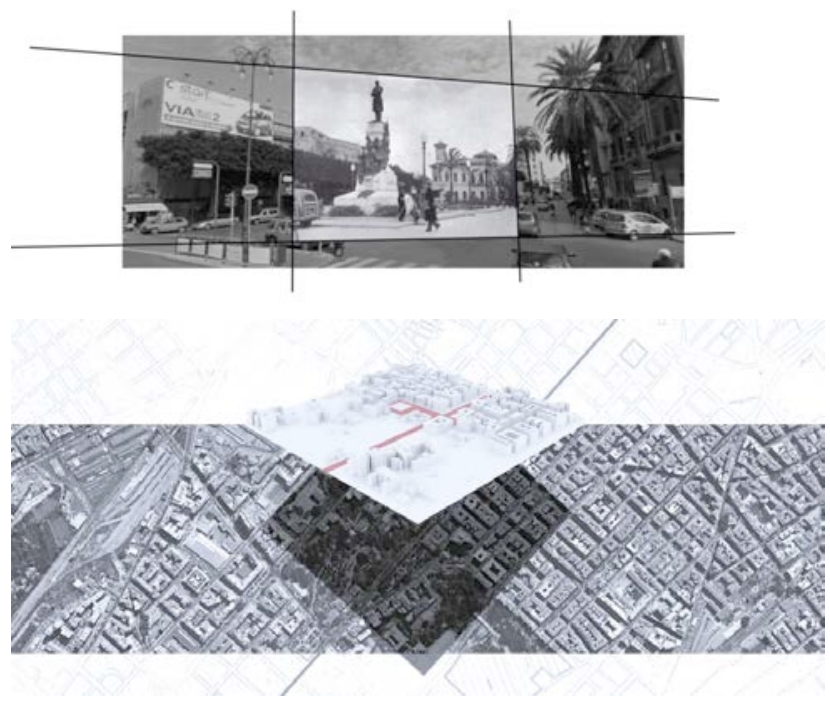

Figure 4. General overview of the plan of the Cross and of the threedimensional model. 

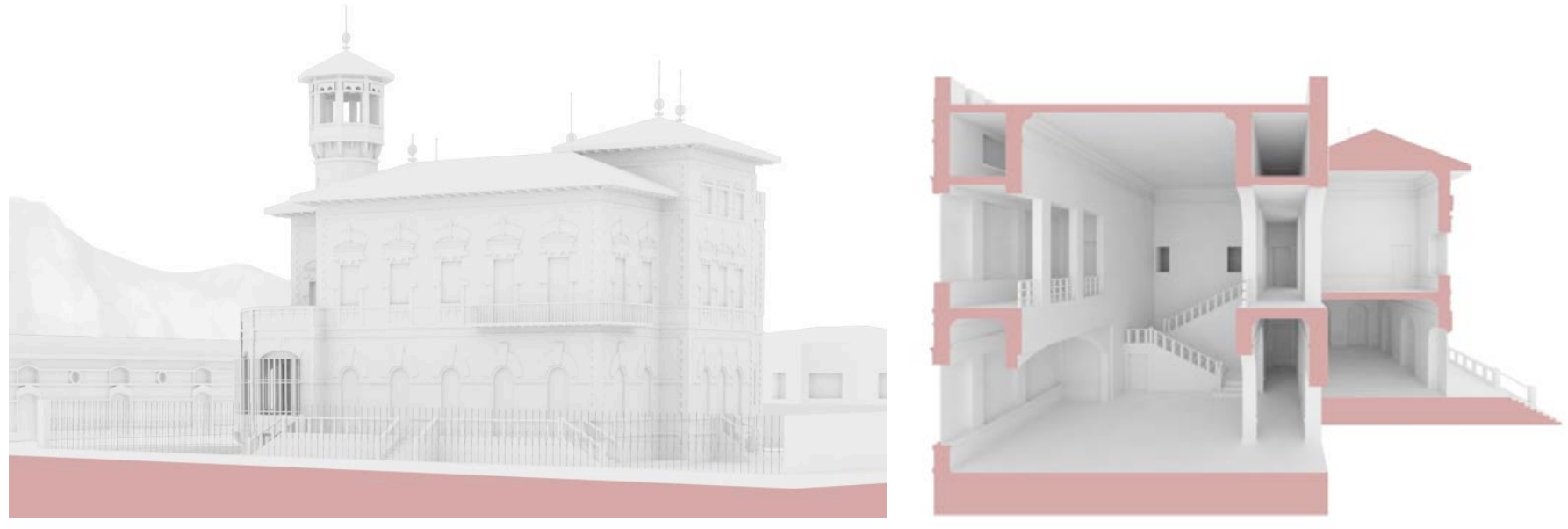

Figure 5. Three-dimensional modeling of villa Deliella inserted within the context of its original architectural landscape; vertical perspective section.
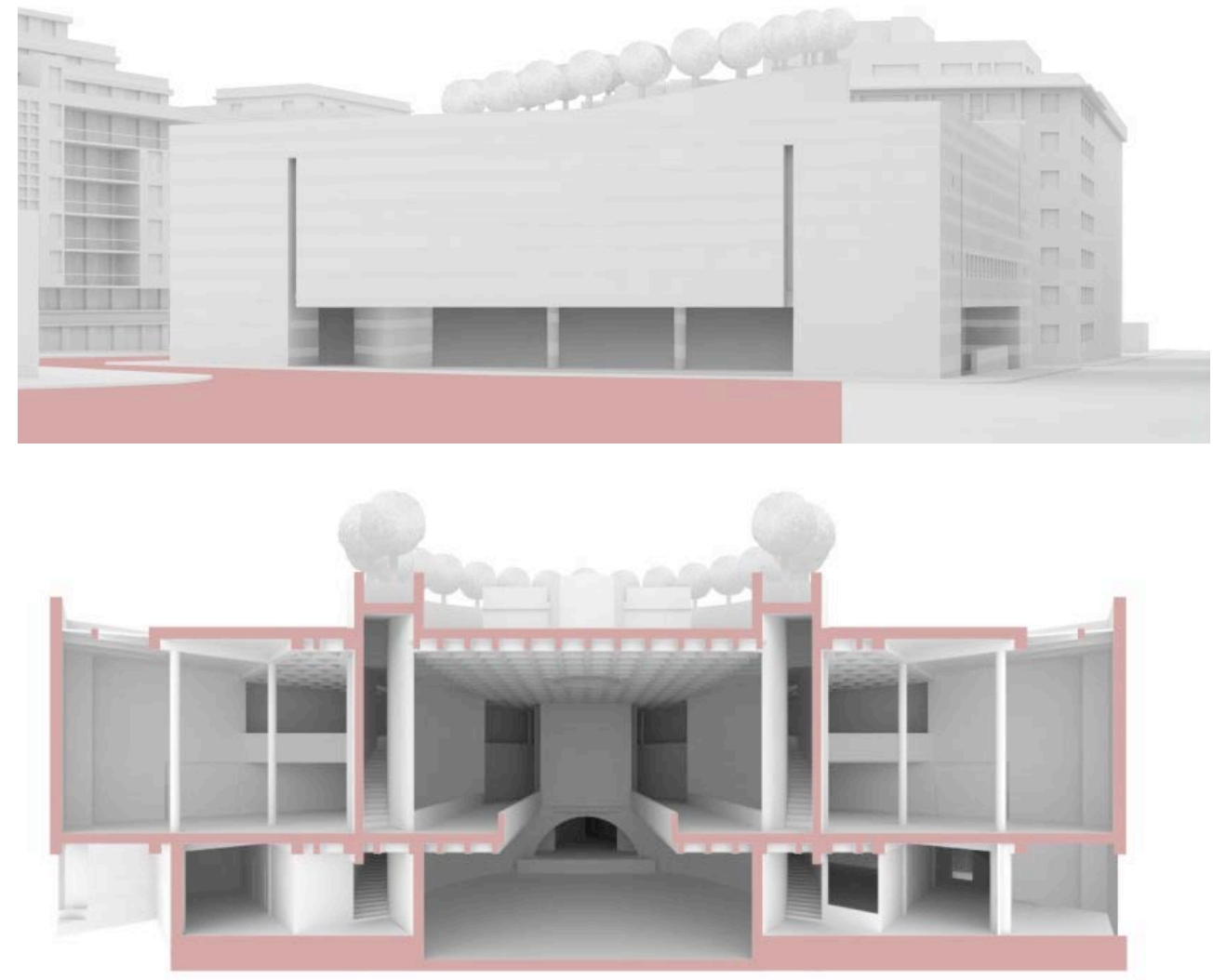

Figure 6. Three-dimensional modeling of the Multimedia Building, West side, North; cross section. 

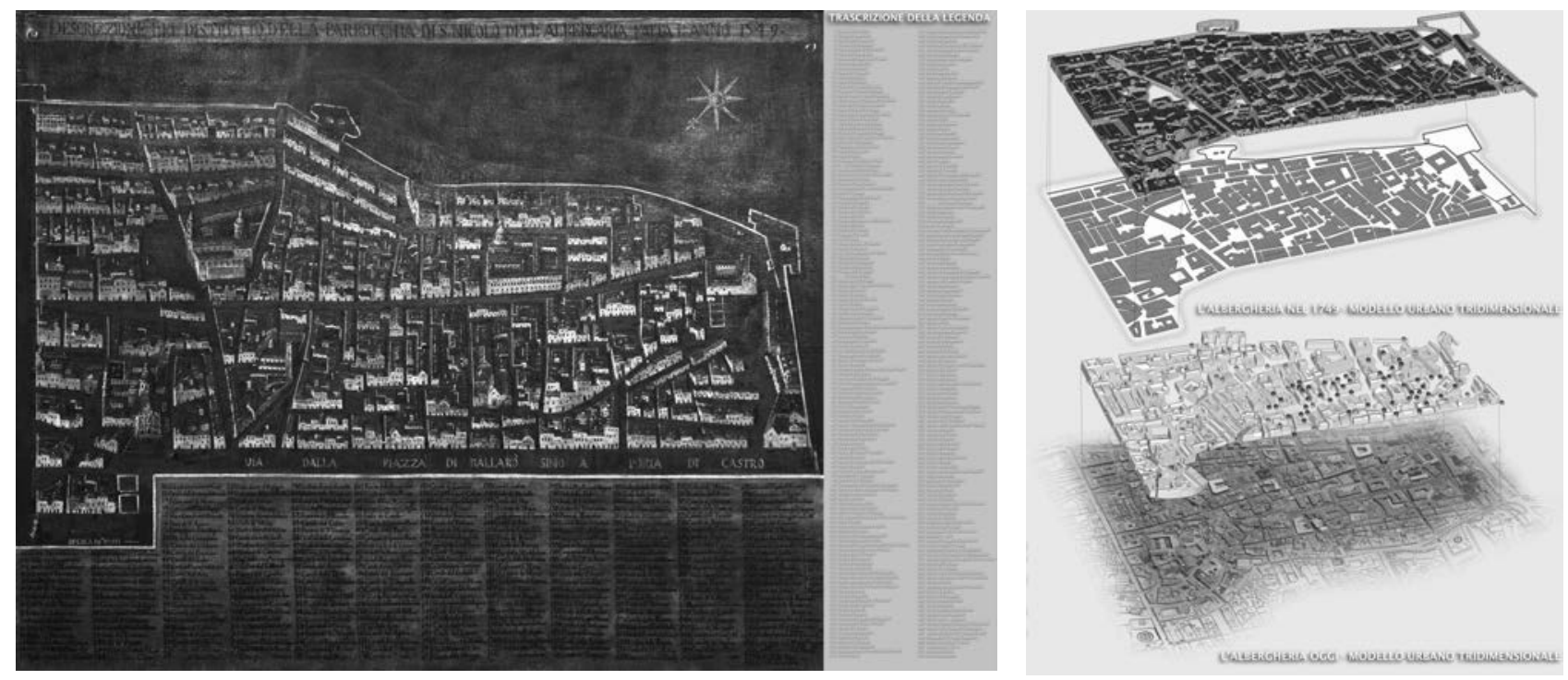

Figure 7. The painting kept at the Diocesan Museum in Palermo; overlap of the two three-dimensional models.

\section{THE AlBERGHERIA DistRICT: A CONJECTURAL RECONFIGURATION OF THE CITY FROM A EIGHTEEN- Century View}

This study suggests a virtual three-dimensional reconstruction of a large urban portion of Palermo Historical Centre modelled on an isometrical view of the 18th century which is entitled Descrizzione del distretto parrocchiale dell'Albergheria fatta l'anno 1749. It is a painting on canvas that has been kept inside the parish of S.Nicolò all'Albergheria, and which in latter days has been taken by the Museum of Palermo Diocese where it is presently exposed to the public[8].

The work presents different levels of interest for the reading of urban ancient morphology which now has disappeared and for the right information of road textures, blocks and monuments represented there: in fact it is possible to identify any element of the painted city because the author has marked each of them with a reference number, and at the bottom of the canvas he has shown the appropriate legend.

The digital elaboration that has been made has been overlayed to a second three-dimensional model that has been got from the present maps of Palermo Historical Centre which describe the present configuration of the quarter: thus the model which derives from the 18th century representation has been referred to the real quotes of the ground and to the elevations of the existing buildings which are illustrated and described in the picture, and it was possible to make a comparison between the two urban configurations. Many items have now disappeared, others have changed through the centuries: the road system was a maze of streets, alleys and courtyards, which now have mostly been replaced with modern roads. Architectures are almost all religious: they are oratories, companies, fraternities, churches and convents, but a few of them are still existing. In the painting the district is surrounded with sixteenth century walls, with a fortification bastion along which the ancient monumental gates in the city stand.

Then all the proposed material has been used to make a new reading of the work and to propose its transformation in a "visual hypertext". All the elements of the picture have been "translated" as file folders, links about the town history and of its monuments, either disappeared or still existing. Then we can create a database of contents as a hypertext, which can be implemented continuously with the addition of new data. The basis of this system is the interactivity and the choice made by the user: all the documents are organized in a network and interconnected via links, and can be reprocessed in infinite combinations, moving quickly from an information to another.

Thanks to the technologies of immersive visualization it is possible to transfer this reading system directly to the museum site: thus the public could have access to the several contents that are proposed by the painting exploring it in real-time; otherwise this wouldn't be possible in today situation[9].

The aim is various: it is not only the study and the discovery of the historical town, but above all it is the proposal of a new method of fruition of art, which is shared by the visitors and strongly subjective, and which has a great touristic potentiality; it shouldn't lose the link with reality and the territory and it should mark it with new meanings.

The hypertext system that has been designed for the framework is organized in different levels of exploration of the work and of its contents.

The first level is relative to the views of the city, to the 
navigation within the two three-dimensional models of the Albergheria neighborhood, which is one of the four quarters that formed the outer part of the Cassaro, the ancient heart of Palermo[10].

Over the centuries it was inhabited by both workers and by wealthy families; many churches were built inside it, many oratories and monasteries are still existing as historical monuments of the neighborhood.

The second exploration level is composed of several virtual tours that are studying the city deeply.

The threated subjects are:

- The existing architectural buildings, which include large groups of religious monuments and even less important monuments -some of them recently restored-, others still in a state of neglect.

- The destroyed architectural buildings, in a virtual tour where it is possible to see some buildings which now are a few remaining ruins and in some cases there is nothing in their original configuration; thus it is possible to make a comparison between past and present.
- The doors and the city walls: this is an itinerary that shows a reconstruction of the medieval walls, with the 15 th century bastions and with the monumental gates of access, simulating a virtual walk.

- The disappeared road system: this itinerary shows the topography of Palermo before the expansion occurred in 19th century outside the walls and the destruction of the fabric of the old town made in 20th century (in part because of the bombings of the Second World War).

With the red trail it is possible to zoom on an area heavily affected by these interventions, overlapping the two threedimensional virtual models.

At any time of exploration it is also possible to select a single element, penetrating into a deeper level of study of the framework and entering the database bonus content: here there are architectural models, drawings, photos and brief descriptive texts[11].
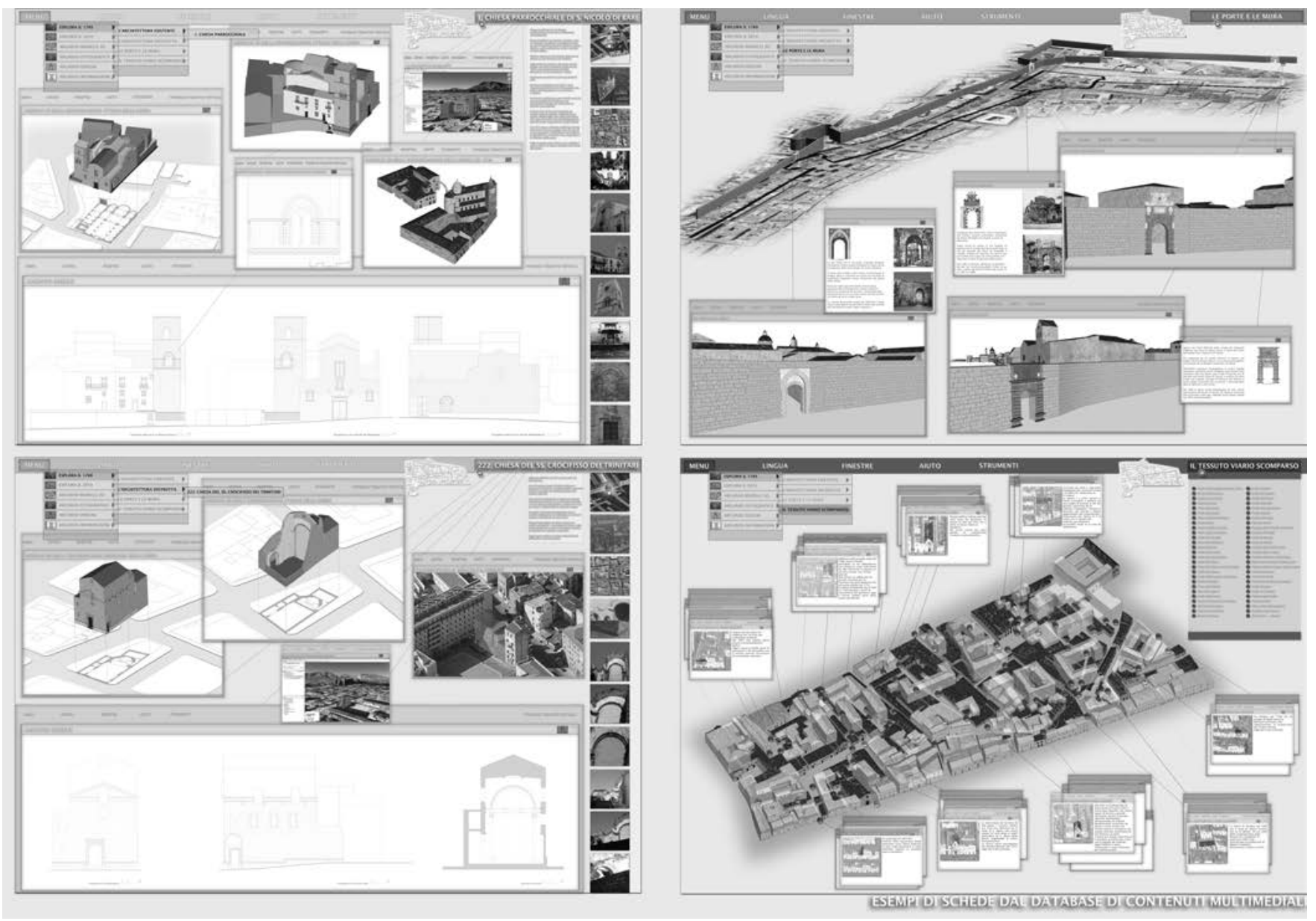

Figure 8. Some forms of hypertext navigation. 


\section{REFERENCES}

[1] The work was carried out in PHD degree laboratories coordinated by G.M. Girgenti at the Faculty of Architecture of Palermo. M. Filippi was involved in the study of Piazza Croci, while F.Marrone worked on the virtual reconstruction of the Albergheria District.

[2] About Basile: S. Caronia Roberti, Ernesto Basile e 50 anni diArchitettura in Sicilia, Ciuni, Palermo, 1935; A. De Bonis, G. V. Grilli, and S. LoNardo, Ernesto Basile architetto: Corderia dell'Arsenale : la Biennale di Venezia 1980, Settore Architettura, Ed. La Biennale, Electa, Venezia 1980; A.M.Ingria, Ernesto Basile e il Liberty a Palermo, Herbita, Palermo, 1987; E.Mauro and E.Sessa, Giovan Battista Filippo ed Ernesto Basile. 70 anni di Architettura. I disegni restaurati della Dotazione Basile 1859-1929, Novecento, Palermo, 2000; A.M. Sciarra Borzì, Ernesto Basile, il Liberty degli architetti siciliani e la tradizione locale rivissuta come memoria creativa, Palma, Palermo, 1982; E.Sessa, Ernesto Basile, dall'eclettismo classicista al modernista.

About the Botta project: V.Fagone, "Progetto per uno spazio multimediale d'arte contemporanea a Palermo" in Per n.9, Palermo, 2004; W. Oechslin, Mario Botta arquitecturas 1980-1990, Editorial Gili-Fundagao, Barcelona-Lisboa, 1992; E.Pizzi, Mario Botta, opere complete, 2 vol., Federico Motta, Milano 1991-94; E.Pizzi, Mario Botta, Zanichelli, Bologna, 1991; R.Baraldi and M.Fiorucci, Mario Botta, Architettura e tecnica, Clean, Ercolano, 1993.

[3] S.M.Inzerillo, Urbanistica e Società negli ultimi 200 anni a Palermo, piani e prassi amministrativa dall"'addizione" del Regalmici al Concorso del 1939, Quaderno n.9 dell'Istituto di Urbanistica e Pianificazione Territoriale della Facoltà di Architettura di Palermo, Palermo, 1984; A.Chirco and M. Di Liberto, Via Libertà ieri e oggi: ricostruzione storica e fotografica della più bella passeggiata di Palermo, Dario Flaccovio, Palermo, 1998.
[4] www.virtualheritage.net; www.fizz.it; www.noemalab.org; http://euromachs.fl.uc.pt

[5] R. Michele, La Sicilia e gli anni 60: vicende e scandali in immagini e parole, la storia torna cronaca, Anvied, Palermo, 1989; B.Zevi, "L'assalto a Villa Deliella" in L'Espresso, 3th of January, 1960.

[6] We thank the Study Botta\&Associates of Lugano and the "Dotazione Basile" of Palermo for all the material and the valuable information.

[7] P.Virilio, La bomba informatica, Raffaello Cortina, Milano, 2000.

[8] We thank the Director of the Museum, Bishop G.Randazzo, and the deputy director, prof. P.F. Palazzotto, for willingness to be granted and for the advice provided.

[9] F. Sparacino, G. Davenport and A. Pentland, Wearable Cinema/wearable city: bridging physical and virtual spaces through wearablecomputing,2000,http://pubs.media.mit.edu/?section=docdeta il\&id=214196\&collection=Media + Lab\&filtercollection=Media+Lab; L.Marchetti, La realtà aumentata di Flavia Sparacino, 2000, www.sensingplaces.com/about/pr/14 Archit.pdf; P.Bussio, "I musei in rete", I-II-III, 2001 in www.noemalab.org/ideas.

[10] G. Bellafiore, Palermo: guida della città e dei dintorni, Istituto Geografico De Agostini Novara, 1956; A.Chirco, Palermo: la città ritrovata, Dario Flaccovio, Palermo, 1997; R. La Duca, Palermo Ieri e Oggi. La città, Sigma Edizioni, Palermo,1990; C. De Seta and L. Di Mauro, Palermo, Laterza, Roma, 1980.

[11] For further information about the contents: G.Spatrisano, Lo Steri di Palermo e l'Architettura siciliana del Trecento, Flaccovio, Palermo, 1972; A.Mazzè, Le parrocchie, Flaccovio, Palermo, 1979; G.Spatrisano, Architettura del Cinquecento in Palermo, Flaccovio, Palermo, 1961; G.Cassata and G.Costantino, Le porte di Palermo attraverso i secoli. Storia e restauro dalle origini a oggi, Epos, Palermo, 1981; C.Filizzola, Le porte di Palermo, Officine Grafiche IRES, Palermo, 1973. 